УДК 39(571.54)

ЦЫРЕМПИЛОВА Ирина Семеновна - доктор исторических наук, доцент; и.о. проректора по научной работе Восточно-Сибирского государственного института культуры (670031, Россия, Республика Бурятия, г. Улан-Удэ, ул. Терешковой, 1; irina161073@таil.ru)

\title{
ОБЪЕКТЫ КУЛЬТУРНОГО НАСЛЕДИЯ РЕСПУБЛИКИ БУРЯТИЯ В СОВРЕМЕННОЙ РЕГИОНАЛЬНОЙ ГУМАНИТАРИСТИКЕ
}

\begin{abstract}
Аннотация. В статье дается обзор основных достижений современных гуманитарных исследований, посвященных проблемам сохранения и использования объектов культурного наследия Бурятии. Богатство и уникальность объектов наследия, их особенности, обусловленные региональной спецификой, история и современное состояние стали предметом интереса специалистов различных областей науки. Автор рассматривает труды ученых, занимающихся изучением археологического наследия; представляет результаты исследований по памятникам архитектуры и истории.
\end{abstract}

Ключевые слова: объекты культурного наследия, Республика Бурятия, памятники, археологическое наследие, гуманитарные исследования

$\mathrm{O}$ дной из насущных задач отечественной теории и практики является преодоление отставания России от многих стран в сфере использования культурного наследия, его активное включение в стратегии устойчивого развития как отдельно взятых регионов, так и страны в целом. Фундаментальная значимость культурного наследия как одного из факторов формирования государственной идеологии и этнонациональной идентичности определяет необходимость анализа тех угроз и вызовов, которые ему предъявляет современное общество. Актуализация культурного наследия обусловлена также его ролью как эффективного ресурса социального и экономического развития. Это определяет необходимость анализа накопленного исследовательского опыта в области изучения, сохранения и использования культурного наследия на территории одного из уникальных регионов России - Республики Бурятия.

Бурятия представляет собой территорию, богатую объектами природного и культурного наследия. Включение озера Байкал в список участков всемирного наследия (1996 г.) является фактом признания исключительной ценности самого озера и прилегающих к нему территорий, которые рассматриваются не только как геолого-географический водосборный регион, но и как уникальное культурное пространство. Этнокультурное явление старообрядцев (семейских) Забайкалья Тарбагатайского района Республики Бурятия было провозглашено ЮНЕСКО «шедевром устного и нематериального наследия человечества» (2001 г.). Уникальность и своеобразие Бурятии обусловлены также ее полиэтничностью и многоконфессиональностью, что привело к синтезу разнородных традиций и укладов, особым формам мультикультурного взаимодействия, от которых напрямую зависит устойчивое развитие общества. В настоящее время на государственной охране в республике находятся 1637 объектов культурного наследия - памятников археологии, архитектуры, истории, монументального искусства.

Из всего массива культурного наследия специалисты особо выделяют археологические памятники. Они представляют собой уникальный феномен и отдельное явление в системе культуры; они имеют ряд существенных признаков, отличающих их от других объектов культурного наследия [Шухободский 2011]. Территория Бурятии исключительно богата памятниками археологии, 
которые предметно отражают все этапы древней и средневековой истории региона, начиная с эпохи палеолита. Ряд памятников, такие как наскальные рисунки, остатки древних стоянок, плиточные могилы, херексуры и др., визуально доступны и являются объектами не только научных исследований. При этом история археологических исследований территории Забайкалья насчитывает более 300 лет - «от редких эпизодических посещений ученых, дипломатов и научных экспедиций XVII - XVIII вв. до систематических, планомерных изысканий сегодняшнего дня» [История Бурятии 2011: 17]. Рассматривая работы, посвященные проблемам сохранения и использования археологического наследия Бурятии, нельзя не отметить достижения археологической науки последних лет. Основные результаты, направления, тематика и оценка исследовательских изысканий ведущих археологов Бурятии (А.И. Бураев, С.В. Данилов, Б.Б. Дашибалов, П.Б. Коновалов, Н.Н. Крадин, Л.В. Лбова, В.И. Ташак, Е.А. Хамзина, А.Д. Цыбиктаров и др.) отражены в ряде публикаций П.Б. Коновалова [Коновалов 2012; 2016а; 2016б].

Одним из значимых результатов археологических изысканий стала научная паспортизация памятников Бурятии (с 1970-х гг.). В целях паспортизации был проведен ряд процедур: визуальный осмотр, внешнее описание, обмер, фотографирование, составление схематического плана, оценка современного состояния памятника. Первый обобщенный результат паспортизации 232 археологических объектов нашел отражение в работе Е.А. Хамзиной «Археологические памятники Бурятии» [Хамзина 1982], затем был расширен и закреплен в совместной с Л.В. Лбовой книге «Древности Бурятии. Карта археологических памятников» [Лбова, Хамзина 1999]. Если в первом издании памятники были объединены по культурно-хронологическому принципу, то во втором издании информация располагалась в соответствии с административно-территориальным делением республики - по 22 районам. Также были рассмотрены вопросы сохранения и использования памятников, историко-культурного ландшафта, археологического картирования Бурятии.

Эти труды следует рассматривать как поэтапную работу для составления тома «Памятники археологии (Свод объектов культурного наследия Республики Бурятия)» (2011). В данном издании представлена информация об объектах археологического наследия - как находящихся на государственной охране (более 700), так и выявленных объектах. Как указано во введении, это «наиболее полная версия всех когда-либо обнаруженных на территории Бурятии местонахождений с остатками человеческой деятельности, называемых стоянками, поселениями, городищами, могильниками, петроглифами (наскальные изображения) и прочими объектами» [Свод объектов... 2011: 4]. Материал представлен в соответствии с современным административным районированием республики с привязкой к сельским населенным пунктам.

В последние годы появились также специальные публикации, посвященные проблемам государственной охраны и использования объектов археологического наследия. Это можно обозначить как положительный накопительный эффект результатов практической деятельности на данный момент единственного в республике аттестованного эксперта по археологии Б.А. Базарова. В его авторских и коллективных статьях рассматриваются актуальные вопросы проведения историко-культурных экспертиз, спасательных археологических работ, вводятся новые материалы по исследованию археологических памятников [Базаров 2018; Базаров, Именохоев, Миягашев 2016; Базаров, Миягашев, Именохоев 2018; Базаров и др. 2016].

С целью популяризации объектов историко-культурного наследия и современного состояния культуры регионов страны в 2002 г. была основана иллю- 
стрированная книжная серия «Наследие народов Российской Федерации». Первым регионом, подготовившим издание под названием «Сокровища культуры Бурятии», стала Республика Бурятия [Наследие народов... 2002]. Большой тираж (3 500 экз.), доступный и легкий стиль изложения, наполненность богатыми иллюстрациями позволили познакомить широкий круг читателей с уникальными материалами.

Большое значение для повышения эффективности государственной системы охраны объектов наследия имеет накопленный исторический опыт. Изучению этого опыта с учетом специфики региональных особенностей посвящена монография Е.В. Вагановой и Е.А. Казки «История охраны памятников историкокультурного наследия в Бурятии (1918-1985 гг.)» (2007).

Памятники архитектуры и истории Бурятии представляют собой объекты культурного наследия, имеющие несомненную историческую и художественную ценность. Своеобразие культурного пространства Бурятии подчеркивается многовековым и устойчивым взаимодействием и взаимовлиянием религиозных конфессий. Особым подтверждением этому служат памятники культовой архитектуры. Они, являясь результатом сложного технического и художественного процесса, обладают не только свойством хранить и передавать информацию, но и свойством эмоционального воздействия. Так, составители «Свода объектов культурного наследия» подчеркнули, что «белокаменные своды православных храмов, затейливое узорчатое кружево деревянных домов, яркие росписи старообрядческих изб, буддийские дацаны, многоярусные с коническим завершением субурганы гармонично вписываются в окружающую нас природу» [Свод объектов... 2010: 4].

В настоящее время на государственной охране РБ находятся 36 сохранившихся объектов культурного наследия религиозного назначения, из них 32 православных храма, 3 буддийских дацана, 1 синагога. Культовые памятники являются объектом исследовательского интереса специалистов различных гуманитарных наук. Классическим образцом фундаментального исследования архитектуры Бурятии до настоящего времени остается научное наследие выдающегося сибирского архитектора, ученого, педагога Л.К. Минерта [Минерт 1983a; 1983б]. Детальное и скрупулезное изучение на основе архивных материалов пионерской для того времени области в истории архитектуры - генезиса бурятской и монгольской архитектуры, буддийской культовой архитектуры в России, а также наличие иллюстраций, фотографий, рисунков, графических реконструкций и др. позволили Л.К. Минерту стать самым цитируемым автором для любого исследователя, занимающегося вопросами культурного наследия Бурятии.

К достижениям современной региональной историографии следует отнести подготовку и издание «Свода объектов культурного наследия Республики Бурятии» (2010). В первом томе «Памятники архитектуры и истории» содержатся историко-градостроительные материалы по памятникам архитектуры и истории. Даны краткие исторические справки, описания объектов культурного наследия, их фотофиксация и планы [Свод объектов... 2010]. В целом Свод представляет собой одновременно справочное и источниковедческое издание, а также может выполнять роль путеводителя по районам республики. Ввиду востребованности информации и ее важности стоит выразить надежду, что книга будет дополнена и переиздана. На наш взгляд, необходим так называемый исторический фон, общая характеристика событий, фактов, явлений, которые бы позволили понять особенности локализации тех или иных объектов культурного наследия. Подобного рода издания должны отличаться качественным справочным аппаратом, а именно наличием именного, географического, 
хронологического указателей. Работа выиграла бы, если была бы персонифицирована, т.е. содержала бы не только информацию о выдающихся личностях, которым были установлены монументы и обелиски, но и сведения об их авторах, скульпторах, архитекторах.

Среди современных исследований выделим труды по истории основания, судьбе и современному состоянию культовых зданий, таких как православные храмы [Жалсараев 2001; Апанасенко 2011; Митыпова 2005; Цыремпилова 2010; 2016], буддийские дацаны [Асалханова 2014; Дулгаров 2010; Жамсуева 2001; 2017; Барданова 2006], архитектурное наследие старообрядцев [Болонев 2004; 2015; Васильева 2007; Долнаков 2015], а также по их архитектурно-художественным особенностям, их значению как объектов культурного наследия.

В качестве положительных примеров следует рассматривать появление с начала XXI в. коллективных работ справочного и энциклопедического характера: «Историко-культурный атлас Бурятии» (2001), «Буддизм. Каноны. История. Искусство» (2006), «Семейские Забайкалья» (2007), «Земля Ваджрапани. Буддизм в Забайкалье» (2008), «Религиозные организации Республики Бурятия» (2011), фотоальбом «Храмы Бурятии» (2014), «Старообрядцы (семейские) Бурятии» (2015) и др. Эти труды не только позволяют представить объективную историю религиозных институтов на территории Бурятии, но и дают оценку их современного состояния.

В качестве самостоятельного направления региональных исследований следует рассматривать тридцатилетние инженерные обследования зданий - памятников истории, архитектуры и культуры, проводимые учеными Восточно-Сибирского государственного университета технологий и управления. Актуальность этих исследований обусловлена высокой сейсмичностью территории республики, в связи с чем необходима оценка технического состояния зданий для проведения антисейсмического усиления и их реставрации [Демин, Панов 2002; 2003; Панов, Дамдинова, Ломова 2016].

Заметное место в региональной историографии занимают исследования В.К. Гурьянова [Гурьянов 1998], которые существенно дополняют историю Верхнеудинска - Улан-Удэ, одного из городов, который «сохранил в своей планировке и застройке генетический код, заложенный градостроительной культурой прошлых столетий» [Гурьянов, Гурьянов 2012]. Также вышли публикации, которые позволяют проследить не только историю и архитектурно-стилистические особенности городов Бурятии (Улан-Удэ, Кяхта), но и современное состояние и перспективы использования архитектурного наследия [Гурьянов 2008; Михалева 2014].

С середины 1990-х гг. в Бурятии на базе Восточно-Сибирского государственного института культуры (в 1995-2015 гг. - Восточно-Сибирская государственная академия культуры и искусств) сформировался научно-исследовательский коллектив, комплексно занимающийся изучением темы «Историческое, культурное и природное наследие: состояние, проблемы, трансляция». Наряду с успешной двадцатилетней подготовкой кадров в сфере музейного дела, охраны наследия и туризма к качественным результатам деятельности вуза следует отнести периодическое издание тематических сборников научных трудов и учебно-методических пособий, организацию и проведение ряда международных и всероссийских научно-практических конференций, подготовку диссертационных исследований.

Таким образом, современные региональные гуманитарные исследования достигли положительных результатов в вопросах изучения объектов культурного наследия Бурятии. Как основное достижение необходимо выделить научно-исследовательскую работу не одного поколения ученых и практиков 
по подготовке Свода объектов культурного наследия Республики Бурятия. При этом необходимы углубление и дальнейшая консолидация исследовательских коллективов по разработке концептуальных подходов и региональных моделей сохранения, трансляции и эффективного использования культурного наследия как важнейшего стратегического национального ресурса.

\section{Список литературы}

Апанасенко С.С. 2011. Православные монастыри как памятники культурного наследия: историко-культурологический анализ (на материалах Республики Бурятия): автореф. дис. ... к.культ. Улан-Удэ. 20 с.

Асалханова Е.В. 2014. Семиотическая значимость орнаментального декора в храмах северного буддизма. - Баландинские чтения. Т. 9. № 3. С. 15-22.

Базаров Б.А. 2018. Институт государственной историко-культурной экспертизы в области археологии в Республике Бурятия. - Республике Бурятия 95 лет: сборник научных статей. Улан-Удэ: Изд-во БНЦ СО РАН. С. 248-251.

Базаров Б.А., Именохоев Н.В., Миягашев Д.А. 2016. Предварительные результаты археологических раскопок на территории объекта археологического наследия «Удинский острог» 2016 года. - Улан-Удэ - 350 лет: история, пространство, общество: сборник научных статей. Улан-Удэ. С. 11-14.

Базаров Б.А., Именохоев Н.В., Миягашев Д.А., Нанзатов Б.3. 2016. Древности Улан-Удэ и его окрестностей. - Вестник Бурятского научного центра Сибирского отделения Российской академии наук. № 2(22). С. 85-98.

Базаров Б.А., Миягашев Д.А., Именохоев Н.В. 2018. Актуализация направления «спасательная археология» в деятельности ИМБТ СО РАН. - Республике Бурятия - 95 лет: сборник научных статей. Улан-Удэ: Изд-во БНЦ СО РАН. C. 251-255.

Барданова Т.И. 2006. Декор в архитектуре бурятских буддийских храмов: автореф. дис. ... к.иск. Улан-Удэ. 17 с.

Болонев Ф.Ф. 2004. Старообрядиы Забайкалья в ХVIII-ХХ вв. М.: ДИК. 352 с.

Болонев Ф.Ф. 2015. Жилище. - Старообрядиы (семейские) Бурятии: 250-летию прибытия первых переселенцев-старообрядиев в Бурятию: историкокультур. энцикл. справочник. Улан-Удэ: ЭКОС. С. 81-83.

Васильева С.В. 2007. Архитектурное наследие деревянного зодчества русского населения Забайкалья: опыт сравнительной характеристики. - Историкокультурное и природное наследие: проблемы сохранения, трансляции и подготовки кадров: материалы всероссийской научно-практической конференции «Проблемы государственного регулирования и управления объектами историко-культурного наследия Байкальского региона». Улан-Удэ, 15 мая 2007 г. Улан-Удэ: ИПК ВСГАКИ. ВЫП. 6. С. 51-55.

Гурьянов В.К. 1998. По Большой, Большой-Николаевской: из истории улии, Верхнеудинска: историко-краеведческий очерк. Улан-Удэ: Изд-во БНЦ CO РАН. 157 c.

Гурьянов М.В. 2008. Архитектурно-градостроительное развитие городов Западного Забайкалья (Баргузин, Селенгинск, Улан-Удэ, Кяхта) до начала ХХ в.: автореф. дис. ... к.арх. СПб. 17 с.

Гурьянов В.К., Гурьянов М.В. 2012. Верхнеудинск ХVII-начала ХХ века. Улицы, городские усадьбы и их обитатели. Улан-Удэ: Изд-во БНЦ СО РАН. 224 с.

Демин Э.В., Панов А.Б. 2002. Инженерное обследование сейсмичности зданий (сооружений) - памятников Троицкого и Селенгинского монастыря. Улан-Удэ: Типография ИП «Гармев С.В.». 172 с.

Демин Э.В., Панов А.Б. 2003. Инженерно-сейсмическое обследование СвятоОдигитриевского собора г. Улан-Удэ. Улан-Удэ. 257 с. 
Долнаков П.А. 2015. К вопросу о храмовой архитектуре семейских. Старообрядчество: история и современность, местные традиции, русские и зарубежные связи : материалы VI Международной научно-практической конференции. Улан-Удэ, 07-08 авг. 2015 г. Улан-Удэ: Изд-во БГУ. С. 339-345.

Дулгаров А.Я. 2010. Архитектурные особенности бурятских буддийских храмов. - Вестник Бурятского государственного университета. № 6. С. 292-296.

Жалсараев А.Д. 2001. Поселения, православные храмы, священнослужители Бурятии XVII-XX столетий: энцикл. справ. Улан-Удэ: Бурятское книжное изд-во. 448 с.

Жамсуева Д.С. 2001. Агинские дацаны как памятники истории и культуры. Улан-Удэ: Изд-во БНЦ СО РАН. 170 с.

Жамсуева Д.С. 2017. Общая характеристика архивных источников по дацанам этнической Бурятии. - Исторические, философские, политические и юридические науки, культурология и искусствоведение. Вопросы теории и практики. № 8(82). C. $88-90$.

История Бурятии. В 3 т. Т. 1. Древность и средневековье. 2011. Улан-Удэ: Изд-во БНЦ СО РАН. 328 с.

Коновалов П.Б. 2012. Археологические исследования в Бурятском научном центре (начало XX - начало XXI вв.). - Вестник Бурятского научного центра Сибирского отделения Российской академии наук. № 3(7). С. 26-48.

Коновалов П.Б. 2016а. Пятьдесят пять лет археологии Бурятского научного центра СО РАН. Ч. 1. - Вестник Бурятского научного иентра Сибирского отделения Российской академии наук. № 3(23). С. 9-20.

Коновалов П.Б. 2016б. Пятьдесят пять лет археологии Бурятского научного центра СО РАН. Ч. 2. - Вестник Бурятского научного центра Сибирского отделения Российской академии наук. № 4(24). С. 10-12.

Лбова Л.В., Хамзина Е.А. 1999. Древности Бурятии: Карта археологических памятников. Улан-Удэ: Изд-во БНЦ СО РАН. 220 с.

Минерт Л.К. 1983а. Памятники архитектуры Бурятии. Новосибирск: Наука. $190 \mathrm{c.}$

Минерт Л.К. 1983б. Архитектура Улан-Удэ. Улан-Удэ: Бурятское книжное изд-во. 248 с.

Митыпова Г.С. 2005. Православие в истории и культуре Бурятии. Улан-Удэ: Республиканская типография. 231 с.

Михалева К.А. 2014. К вопросу о формировании архитектурного наследия исторических городов Бурятии. - Международный научно-исследовательский журрнал. № 7-1(26). С. 76-80.

Наследие народов Российской Федерации. Вып. 1. Сокровища культуры Бурятии. 2002. М.: НИИЦентр. 317 с.

Свод объектов культурного наследия Республики Бурятия. Т. 1. Памятники архитектуры и истории. 2010. Улан-Удэ: Республиканская типография. 326 с.

Свод объектов культурного наследия Республики Бурятия. Т. 2. Памятники археологии. 2011. Улан-Удэ: НоваПринт. 388 с.

Панов А.Б., Дамдинова Д.Р., Ломова Н.М. 2016. Инженерно-сейсмическое обследование зданий - памятников истории, архитектуры и культуры Республики Бурятия. - Вестник Восточно-Сибирского государственного университета технологий и управления. № 3. С. 18-23.

Хамзина Е.А. 1982. Археологические памятники Бурятии. Новосибирск: Наука. $152 \mathrm{c}$.

Цыремпилова И.С. 2010. Проблемы сохранения и использования православного культурного наследия в контексте государственно-церковных взаимоот- 
ношений в 1920-1930-х гг. (на материалах Байкальского региона). - Власть. № 7. С. 144-150.

Цыремпилова И.С. 2016. Музеефикация культового наследия на территории Байкальского региона в 1930-е гг:: к постановке проблемы. - Иркутский историко-экономический ежегодник. Иркутск: Изд-во БГУЭП. С. 379-385.

Шухободский А.Б. 2011. Объект археологического наследия как отдельный феномен культурных ценностей. - Общество. Среда. Развитие. № 4. С. 136-140.

TSYREMPILOVA Irina Semenovna, Dr.Sci. (Hist.), Associate Professor; Vice-Rector of East Siberian State Institute of Culture (1 Tereshkovoj St, Ulan-Ude, Republic of Buryatia, Russia, 670031; irina161073@mail.ru)

\title{
OBJECTS OF CULTURAL HERITAGE IN THE REPUBLIC OF BURYATIA IN CONTEMPORARY REGIONAL HUMANITARISTICS
}

\begin{abstract}
The article gives the review on main achievements of contemporary humanitarian studies, devoted to the problems of conservation and usage of objects of cultural heritage of Buryatia. The richness and uniqueness of heritage objects, their peculiarities determined by regional specifics, history and current state are the objects of interest of specialists in various fields. The author analyzes the works of scientists, studying the archeological heritage and presents the results of researches on samples of architecture and history.
\end{abstract}

Keywords: objects of cultural heritage, Republic of Buryatia, monuments, archeological heritage, humanitarian studies 